\title{
On Rendering French Syllabic Verse in Estonian Language: Reflections and Proposals ${ }^{1}$
}

\section{Ants Oras}

In recent times we have witnessed - most notably due to the popular work of Johannes Semper - an increase in the number of Estonian renditions of French verse. This, however, raises issues concerning the method of translation. I have been interested for a long time in the question of how to render French meter, especially alexandrine (that is, the iambic hexameter, according to the conventional definition). The main difference in the general use of versification methods lies between the French practice of the so-called syllabic and our practice of tonic meter (with the exception of folklore). According to the most common understanding, this means that the French count the number of syllables, whereas we count the number of stresses. The stress placement in verse lines for us is mostly predetermined, while in French verse both the number and position of stress varies. It has been widely held that our traditional and indigenous method cannot be altered even when translating French verse, and that therefore the most classical and well-known form of French verse - the alexandrine - must be bent into conformity with our schemes and rules. The scheme for the Estonian iambic hexameter is plain and simple: $\cup-\cup-\cup-\cup-\cup-\cup-(\cup)$. This is the very form that has been used in most cases for rendering French poetry into Estonian. I will illustrate this by juxtaposing the first two stanzas of Johannes Semper's translation of Baudelaire with the original:

La Nature est un temple où de vivants piliers

Laissent parfois sortir de confuses paroles;

L'homme y passe à travers des forêts de symboles

Qui lobservent avec des regards familiers.

1 The paper was published in 1931 in Estonian literary journal "Eesti Kirjandus" and was translated from Estonian by Miikael-Aadam Lotman. 
Comme de longs échos qui de loin se confondent

Dans une ténébreuse et profonde unité,

Vaste comme la nuit et comme la clarté,

Les parfums, les couleurs et les sons se répondent.

On Loodus tempel elavate sammastega,

Kust sõnu vahel poetub ebamääraseid.

Käib inimene hiien keset sümboleid,

Mis vaatavad teda tuttavate pilkudega.

Kui ühineksid kaugel pikad vastuhelid

Ja sulaksid kõik sügavusen üksuseks,

Mis suur kui öö, kuid ometi liig kauge seks,

Nii vastavad üksteist lõhnad, värvid, helid.

The difference is radical. It stems mainly from two aspects: first, there is no consistent caesura in Estonian verse that divides each line after the third foot (that is, after the sixth syllable) into two hemistiches, secondly, there is a remarkable variety of rhythm types in French verse, but the rather monotonous scheme that permeates Estonian verse (albeit varying in terms of specific word-length, and so on) does not generally capacitate conversion techniques equivalent to French language. I must emphasise that the divergence is caused by the general scheme rather than its particular realisation. Even though French meter is called "syllabic", the tonic aspects seem to play substantially into the equation, since the syllables cannot be read without using the natural word-stresses. Such feature can be expressed in terms of tonic versification. When each line from Baudelaire's example is divided into hemistiches, we get a total of sixteen units. Analysis reveals that ten units out of sixteen are anapaestic:

\section{La Natùre est un tèmple} de confùses paròles, etc.

Three of the sixteen units can be considered iambic, if we take into account the secondary stresses and certain ramifications of the general scheme. The three remaining units could be called iambic, were it not for the first (trochaic) foot, which is inverted with respect to the second. In some cases this adds special emphasis and gravity to the word corresponding to the inverted trochaic foot, as can be seen here: Vaste comme la nuit (incidentally, in this case both feet are trochaic) - 'vaste', an already weighty and significant word, is brought more vigorously to the fore. Experiments I have conducted with a whole number of 
other poems by Baudelaire indicate that the ratio is quite similar to the poem analyzed above: anapaestic rhythm is the most common, even though fully anapaestic alexandrine lines hardly ever exceed 50\%. Mixed-type alexandrines seem to predominate, that is, lines where only the first or second half is anapaestic and the corresponding other halves mostly - though not always - consisting of a purely or nearly iambic structure with frequent inversions of singular verse feet. Cases where an anapaestic foot appears only in the second hemistich seem to predominate, giving me a general impression that the rhythm of the French alexandrine is closer to anapaest rather than to iamb. Since this tentative conclusion is supported by extremely limited statistical material, it should not be expected to hold true for Baudelaire's poetry in general, much less for the whole of French poetry. In any case, anapaest is seemingly more frequent than iamb in alexandrine, which is characterised above all by a shifting from meter to meter. The shift: iamb > anapaest induces acceleration of movement, whereas the reverse induces deceleration. This is mostly due to the reduction of stressed syllables to two units in anapaestic parts, as opposed to the three stresses in iambic half-lines. Thus the number of stressed syllables fluctuates between four and six stresses in the typical alexandrine. Below are a couple of lines from the poem cited above illustrating acceleration:

Laissent parfois sortir de confuses paroles...

Comme de longs échos qui de loin se confondent...

An illustration of deceleration:

La Nature est un temple où de vivants piliers...

These two types seem to be the most common in French, or at least Baudelaire's, alexandrine. The most compelling cases of acceleration and retardation can be seen, however, when a purely anapaestic line is followed by a uniformly slow line, or vice versa. I will give a few more examples, also from Baudelaire:

Heureux celui qui peut d'une aile vigoreuse

Sélancer vers les champs lumineux et sereins!

(“Élévation")

[Tu te rappelleras la beauté des caresses]

La douceur du foyer et le charme des soirs,

Mère des souvenirs, maîtresse des maîtresses!

(“Le Balcon”) 
Let us now compare the cited French lines with a few original - and intrinsically appealing - alexandrines from Gustav Suits:

Veel purskab tuld ja suitseb sõja kuri kraater,

kui valguse uus andja avand alma mater

siin oma uksed vanad veerul vaikse mäe,

mis esimest, ei viimast rõõmupidu näe.

(“Õnnesoov” [Felicitation])

Here are a few lines from "Leconte de Lisle’i läkitusest sõbrale" [Leconte de Lisle's message to a friend]

Nüüd Revolutsiooni üle võime panna ristid,

Louis, sõber õiguse, töötoa ja raamatu,

kui Asutavas Kogus koos legitimistid, töövabariik me pelvis kättesaamatu.

Bourboni saartele me taoline tõtku, provintsi Prantsuse pääkurat ise võtku!

Bretagne’i mullust kui veel sõitu mälestan, me rahva juhmust-jahmust jälestan.

Alliterations, novel rhymes, internal rhymes, borrowed words and inversions in word order make the Estonian verses, which otherwise sound rather monotonous, more interesting. This is apparently the impetus behind accelerated shortenings and retarding lengths of lines as illustrated in the second example. Such possibilities are ever-present in the typical French form, but as we have already seen, there is an additional array of diverse possibilities that are lacking in our alexandrine. Our alexandrine is, quite understandably, far less acclimatised than the corresponding form in France.

Similar, or roughly similar, constraints seem to bind generally all literatures that share the tonic meter. Many different paths have been pursued in order to overcome such difficulties. The English, with their time-honored techniques, were unable to find a suitable counterpart for rhymed alexandrine couplets in the form of nuanced yet less expressive heroic distiches. In recent times, all manner of longer metric forms have come to be substituted, depending on the mood. The monotony of shorter lines has been aptly avoided by introducing vibrations similar to French verse with the help of stress inversions - an 
English versification technique acculturated since long ago - and short, barely discernible, additional syllables:

... And Charles the Seventh, that worthy one?

Even with the good knight Charlemain.

(Swinburne's translation of Villon)

Seventh can occur either as a mono- or disyllabic word: a slight trembling of a syllable is felt in normal pronunciation. The beginning of the second line contains a stress inversion.

Germans - with some interesting exceptions, such as the translations by Otto Hauser - tend either to hold on to their humdrum iambic hexameter or to use a form in which the amount of stresses remains the same while the number of syllables varies. The latter can add dynamism, but it reduces the general impression of balance and orderliness, which accounts for some of the major traditional appeals of French verse. This, in my opinion, is one of the contributing reasons why Stefan George's oft admired translation of Baudelaire isn't completely satisfactory. Sophisticated though it may be, at times it misses the original's dynamism, at times its measured buoyancy, depending on whether he prefers a clear iamb or drifts into a more chaotic verse instrumentation that does not keep exact count of syllables.

Our language has had to face the same dilemma. Johannes Aavik's Estonian renditions of Baudelaire are composed in clear-cut iambs with a more or less demarcated caesura. The form in the translation of Une Charogne [Raibe], published in the III edition of the proceedings of "Noor-Eesti", does not pall because the alexandrine regularly alternates with an altogether shorter verse. In the same volume, Gustav Suits published his Estonian version of Elévation [Prantsuse bukett] too. His translation has an anapaestic meter that befits the said poem. In a longer piece such meter might have become tedious, but in this case it is enthralling:

Au-dessus des étangs, au-dessus des vallées,

Des montagnes, des bois, des nuages, des mers,

Par delà le soleil, par delà les éthers,

Par delà les confins des sphères étoilées...

Üle tiikide, loikude, nõgude nõre,

üle metsade, mägede, pilvede,

kaudu eeterimere ja päikese,

läbi viimaste tähtede laotuse õre... 
As we can see, this form corresponds to the strong rise in the onset of the original. Semper's later rendition of Bénédiction [Õnnistus] is amphibrachic throughout (with an occasionally omitted syllable) and has the same forceful effect as the original, but some of its diversity is lost due to the very choice of form, at least in the more lyrical or subtle parts:

- Soyez béni, mon Dieu, qui donnez la souffrance

Comme un divin remède à nos impuretés

Et comme la meilleure et la plus pure essence

Qui prépare les forts aux saintes voluptés!

"Oo Issand, sind kiidan, sult kannatust saad,

See jumalik rohi, mis puhastab rooja,

See lõhnav õli, mil säilitav laad,

See pühale himule aseme looja."

It seems to be the relative inflexibility of the form that forces Semper into simplifying the substantial features of the poem and delineating its contours more robustly. On the one hand, Baudelaire's priestly abstractness has been reduced, but on the other hand, Semper's verses stand out with a particularly concrete freshness.

We can conclude from all of the above observations that verse forms chosen thus far to substitute French alexandrine do make it possible to write fine Estonian poetry, but fail to adequately reflect the amply vibrant manner of the original.

\section{3}

The question arises whether there are any possibilities for a more accurate reproduction of the French rhythms. All of the rhythm types mentioned in the first part of this article are present in the Estonian language, thus, they can be employed for translating verse. Caesura presents a more formidable difficulty and its consistent implementation is not an easy task, since our language does not have strong final stresses to mark pauses. I suggest that it should be implemented at least to the extent of establishing a mental image of the scheme. This also applies to anapaestic lines, where the caesura can be omitted in quite a few cases, without the fear of forgetting the general structure. Anapaestic lines that have a caesura would compensate for lines that lack it. They would be accommodated into the scheme by analogy. Anapaestic lines 
have to be treated with the most care in this regard. Caesuras in iambic parts can also be marked with a weak secondary stress where necessary, at least in cases where it is succeeded by a weighty punctuation mark, although this is unfortunately impossible for fast-paced anapaests. In general, it seems likely that an alexandrine composed in this way is more lenient in the placement of pause than its classical French counterpart, resembling to a certain extent the type of alexandrine used by French romanticists.

The main rule would consist in the identical number of syllables + the maintained predominance of verses with caesurae. The rhythm is not necessarily less diverse than in French language, although some cases, for instance, the collision of two strongly stressed syllables, are less likely to become a characteristic of Estonian verse. Should the proposed form become customary, it would result in a considerable increase in the liberty of movement without conceding the impression of regularity.

I have conducted experiments in an attempt to implement the aforementioned principles. At first I experimented with some of the more characteristic types of alexandrine. Thus, I translated Baudelaire's Harmonie du soir [Õhtu harmoonia] according to the scheme: 3 iambs +2 anapaests.

Näe õhtu saabumist, nüüd, mil tuulingu haar

õisrühmist viirukit tõstleb hilju ja sala;

hõng tiirleb, sõõrleb ses hääle hämara hala;

sünk valss, mu valule videv, peidukas saar!

However, I soon abandoned that plan, giving a freer rein to the rhythm, as can be seen, for example, in the following lines from the poem Que diras-tu ce soir:

Keset üksildast ööd, kitsast tänavakurdu, kesk mõtlust vaikivat ja rahvaparve murdu tantsleb ta viirastus õhus kui tunglatoit

Mõnikord lausub see: "Rada mu pälvurkonna viib vaid ilule, ilu ta, nälgiva, toit! Olen ingel ja kaitsja ja muus ja madonna!

(Que ce soit dans la nuit et dans la solitude, Que ce soit dans la rue et dans la multitude, Son fantôme dans l'air danse comme un flambeau. 
Parfois il parle et dit: "Je suis belle, et jordonne

Que pour l'amour de moi vous n'aimiez que le Beau;

Je suis l'Ange gardien, la Muse et la Madone!")

The Estonian text should indicate that even the inversion of stress within verse feet can be implemented without ruining the unity. "Tantsleb ta viirastus õhus kui tunglatoit..." corresponds to the trochaic beginning in the half-line ... danse comme un flambeau and most probably helps to highlight the fluttering rhythm described therein.

Most of the novelty of the current proposal lies in methodological persistency. Undoubtedly the techniques described in this paper have been implemented in separate cases, but as far as I know, nobody has ever tried to organise them with the purpose of devising a regular type of verse, much less for the rendition of French verse. This method will probably take some getting used to and it obviously needs refinement and diversification. Thus far merely its contours have been outlined. I will add a few shorter translations from "The Flowers of Evil", which has been our sole material for illustrations, in order to draw a rough sketch of what the end result would look like. I must stress here that a far greater diversity (alongside with more satisfactory caesuras and more precise adherence to the model of French verse) could be achieved in more adept hands. With the following I will merely present a few fumbling attempts:

\section{EKSOOTILINE LÕHN}

Kui uimastab mind hõng su rinnast, hõrk ja palav,

sügisõhtuti, ilm mil hääletu ja kuum,

kinnisilmade ees kauge ranniku ruum

üle päikene, üksluiselt helendust valav;

saar õnnelik ja laisk, kus loodus üliküllas

toodab saledaid puid, mil võorraid vilju murd;

kus väike meestetõug näib visa ja turd,

ja naiste kiirgav pilk imejulge ja üllas.

Ning kauneid valgmaid näen su hõngust, mille kais

maste otsatu hulk, lõtvuv purjede pais

veel väsind iilidest, millest merestik puljas,

kuna lõhn, mille levitab lai tamarind, mis sõõrmeid paisutab, millest oakitseb rind,

liitub lauluga laevult, mis kutsuv ja uljas. 


\section{ALBATROSS}

Vahel naljale isukas madruste summ saab kätte albatrossi, vete võimsa looma, kes õhus tiireldes, loid saatja, suur ja tumm, jälgis liugleva purjeka valkavat jooma.

Vaevalt laskus, kel uhkena sirutus kael, alla laotuse vürst, kui äratav vaid naeru! Kui raskelt lohiseb laeva tõrvasel lael ta valge tiivapaar - kaks nii abitut aeru!

Taeva kartmatu poeg, kes eetris hõljendab, kuis nüüd mannetuks jäänd, kuis saamatuks ja lonkab! Siin komberdades mees ta käiku jäljendab, sääl teine narrides tal piibu näkku tonkab.

Nagu pilvede vürst, nii ka sina, poeet! Ei tend heidutatand torm, ei nool hukkuva ammu, ent, alla kõrgustest naerukärasse veet, tema hiiglasetiib tal vaid takistab sammu. 